\title{
Seasonality effect on ant (Hymenoptera: Formicidae) activity in an ecotonal environment in the state of Piauí, Brazil
}

\author{
Vinícius Lima de Miranda ${ }^{1,7}$; Elmo Borges de Azevedo Koch $^{2,8}$; Laine da Silva Oliveira ${ }^{3,9}$; Joanes de Jesus Moreira Nunes ${ }^{4},{ }^{10}$; \\ Diogo Brunno e Silva Barbosa ${ }^{3,11}$; Maria Regiane Araujo Soares ${ }^{3,12}$; Cléa dos Santos Ferreira Mariano $0^{5,13}$ \& \\ Jacques Hubert Charles Delabie ${ }^{2,6,14}$
}

1 Universidade de Brasília (UNB), Instituto de Ciências Biológicas (ICB), Departamento de Zoologia. Brasília, DF, Brasil.

${ }^{2}$ Comissão Executiva do Plano da Lavoura Cacaueira (CEPLAC), Centro de Pesquisas do Cacau (CEPEC), Laboratório de Mirmecologia. Ilhéus, BA, Brasil.

${ }^{3}$ Universidade Federal do Piauí (UFPI). Floriano, PI, Brasil.

${ }^{4}$ Museu Paraense "Emílio Goeldi" (MPEG), Campus de Pesquisa, Coordenação de Ciências da Terra e Ecologia (COCTE), Laboratório de Morfologia e Ecologia Funcional de Formigas (ANTMOR). Belém, PA, Brasil.

${ }^{5}$ Universidade Estadual de Santa Cruz (UESC), Departamento de Ciências Biológicas (DCB), Laboratório de Artrópodes Sociais. Ilhéus, BA, Brasil.

${ }^{6}$ Universidade Estadual de Santa Cruz (UESC), Departamento de Ciências Agrárias e Ambientais (DCAA). Illhéus, BA, Brasil.

7 ORCID: https://orcid.org/0000-0003-1788-0959. E-mail: viniciuslimabio@gmail.com

${ }^{8}$ ORCID: https://orcid.org/0000-0002-2022-4066. E-mail: elmoborges@gmail.com

9 ORCID: https://orcid.org/0000-0002-3681-3025. E-mail: laineoliveira001@gmail.com

${ }^{10}$ ORCID: https://orcid.org/0000-0001-8598-3461. E-mail: joanes2015@gmail.com

${ }^{11}$ ORCID: https://orcid.org/0000-0003-1377-6601. E-mail: diogo_brunno@yaho0.com.br

${ }^{12}$ ORCID: https://orcid.org/0000-0002-2428-2052. E-mail: regianebiologa@yahoo.com.br

${ }^{13}$ ORCID: https://orcid.org/0000-0001-7188-8201. E-mail: camponotu@hotmail.com

${ }^{14}$ ORCID: https://orcid.org/0000-0002-2695-1061. E-mail: jacques.delabie@gmail.com

\begin{abstract}
This study aimed to compare the activity of ants during the rainy and dry seasons in a transitional environment (ecotone) at the interface of Cerrado and Caatinga biomes situated in the state of Piauí, where studies of local ant fauna are still incipient. The research was carried out at Floriano, state of Piauí, Brazil. Ants were sampled during the rainy season in December 2018 and during the dry season in June 2019. Three parallel transects were established at least $100 \mathrm{~m}$ apart. At each point, three sampling methods were used, with attractive baits placed on the trees and ground, and pitfall traps on the ground. Thirty-one ant species belonging to 14 genera and five subfamilies were collected, with 27 recorded in the rainy season and 17 in the dry season. The only species reported with the three collection methods and the two seasons was Camponotus crassus Mayr, 1862. Seven ant species sampled in this study are new reports for the state of Piauí. There was a significant difference in the average number of ants and the composition of the assemblages between the rainy and dry seasons. We demonstrate that the activity of ants is influenced by seasonality, corroborating our hypotheses. This is only the second study on ant diversity in the state of Piauí, and more studies are necessary to understand the processes and factors which regulate the activity patterns of ants in ecotonal situations like those observed in this region.
\end{abstract}

Keywords. Myrmecofauna; Ant diversity; Ecotone; Dinoponera quadriceps; Abiotic factors.

\section{INTRODUCTION}

Ants are eusocial insects prominent in terrestrial ecosystems because of their wide geographical distribution, abundance, and species richness (Hölldobler \&Wilson, 1990; Alonso \& Agosti, 2000; Vasconcelos et al., 2001; Jory \& Feitosa, 2020). Brazil has the most remarkable diversity of ants in the Americas, and one of the most extensive globally, registering more than half of the species described for the Neotropical Region, which corresponds approximately to 1,500 species distributed in 112 genera (Bolton, 2021).

In the state of Piauí, northeastern Brazil, 152 ant species distributed in 53 genera and nine subfamilies were reported in 24 sites sampled (Jory \& Feitosa, 2020). This state requires prioritization in terms of diversity studies, since it presents an ex- 
tensive transition zone between three Brazilian biomes, the Atlantic Forest, Cerrado, and Caatinga (Jory \& Feitosa, 2020), while only basic information is available on the ant fauna in this region.

Transition zones or ecotones are areas where different biomes meet, with marked environmental gradients (Kark \& Rensburg, 2006) that can occur on multiple spatial and temporal levels. They are related to the strength of interactions between adjacent ecological systems, which can vary from wide interfaces between biomes to small-scale local transitions (Holland, 1988; Gosz, 1993). Ecotones with large territorial extensions may present different characteristics from the central areas of the biomes in aspects such as rainfall variations and oscillations of environmental variables (Smith et al., 1997). In addition, these differences can have relevant effects in some animal groups when associated with other factors such as genetic isolation, resulting in phenotypic differentiation and speciation (Smith et al., 1997). Studies in ecotone areas are still lacking, particularly in transition areas with the Caatinga biome (exceptions are Silva et al., 2017 and Neves et al., 2013). The conservation of the diversity of these transitional environments is extremely important, as they are characterized by a mosaic of vegetation and certainly influence the species living in the surrounding environments (Neves et al., 2013). Understanding the factors responsible for the coexistence, biology, and variations in the activities of ants according to the characteristics of these environments is essential for understanding local and regional ant diversity.

The Cerrado is considered the largest Brazilian biome, with a high species richness that probably represents 33\% of the country's biological diversity (Aguiar et al., 2004; Klink \& Machado, 2005). Due to its favorable topographic conditions, soil types, and climate with well-defined seasons, this biome has been deforested on an accelerated scale essentially for livestock and industrial agriculture (Aguiar et al., 2008). In response to this growing exploitation by human activities, the diversity of ants in this biome has mainly been studied to understanding the disturbances caused to natural environments, such as in Eucalyptus monoculture (Majer, 1996; Marinho et al., 2002; Silva \& Delabie, 2014); otherwise, their use as bioindicators of preserved and degraded lands was highlighted (Brandão et al., 2011; Tibcherani et al., 2018).

In contrast to the Cerrado, the Caatinga, a predominant biome in the Northeast region of Brazil, is considered a poor biome in species and therefore has less studied when compared to other phytogeographic regions of the country (Leal, 2003). However, this biome constitutes an important biological heritage because it houses many endemic animals and plants (MMA, 2017; Leal, 2003). Studies related to ant diversity have already been carried out in this biome, with an emphasis on environmental monitoring (Leal, 2003; Nunes et al., 2011; Freire et al., 2012). Knowledge on other biological aspects related to diversity yet is still scarce, and the effects of seasonality on the coexistence and activity of ant species are poorly understood (Ulysséa \& Brandão, 2013).
Despite the increase in studies in recent years on ant fauna in the Caatinga and Cerrado (for example, Neves et al., 2013), several questions about the structure of the communities remain. Due to the shortage of research on ants in the state of Piauí and the growing threats to diversity resulting from the loss of habitats (Divieso et al., 2020), there is a need to understand the structure of the community of these organisms. In this study, we sought to answer the following questions: (i) Which ant species occur in a transitional environment between the Caatinga and Cerrado biomes in the state of Piauí? (ii) Does ant activity differ according to seasonality? We hypothesized that the ant activity is more significant during the rainy season, when factors that usually determine the species richness and community composition (food and nesting resources, environmental heterogeneity, and abiotic factors) are more readily available compared to the dry season. We expect that ant arboreal and soil predators have a marked activity during the rainy season, while generalist and opportunistic species dominate otherwise.

\section{MATERIAL AND METHODS}

\section{Study area}

The study was carried out at the Fazenda Experimental Novo Recreio (collecting permit ICMBio/SISBIO \#64030-1), in a transitional area between the Caatinga and Cerrado biomes in the municipality of Floriano, Piauí $\left(06^{\circ} 46^{\prime} 01^{\prime \prime} \mathrm{S} ; 43^{\circ} 01^{\prime} 22^{\prime \prime} \mathrm{W}\right.$; Fig. 1). The regionals climate is characterized as semi-arid tropical, with temperatures varying between $21^{\circ} \mathrm{C}$ and $38^{\circ} \mathrm{C}$, with a six-month dry period (May to October) and a rainy period between November and April (INMET, 2019).

\section{Ant sampling}

Ants were collected in December 2018, during the rainy season, and in June 2019 during the dry season (at the same points in both seasons). Three parallel transects were established, at least $100 \mathrm{~m}$ apart, with a distance of at least $50 \mathrm{~m}$ from the edge. We defined 10 sample points in each of these transects, at intervals of $20 \mathrm{~m}$. At each point, the ants were collected using three different methods: (i) a pitfall trap in the soil (pitfall trap). A $500 \mathrm{~mL}$ disposable plastic cup with a diameter of $10 \mathrm{~cm}$ and a depth of $19 \mathrm{~cm}$ was used as pitfall trap, which was half-filled with a solution composed of water and neutral detergent. The pitfalls remained active in the field for $48 \mathrm{~h}$; (ii) a sardine in comestible oil bait disposed on the ground (soil bait), and (iii) a sardine in comestible oil bait on the nearest bush or tree (tree bait). In the two last cases, tubes (Falcon type) containing small pieces of sardine in comestible oil were used for the baits, which remained active for two hours. We consider the three samples obtained with the different methods as a composite sample at each sampling point. These methods are commonly 


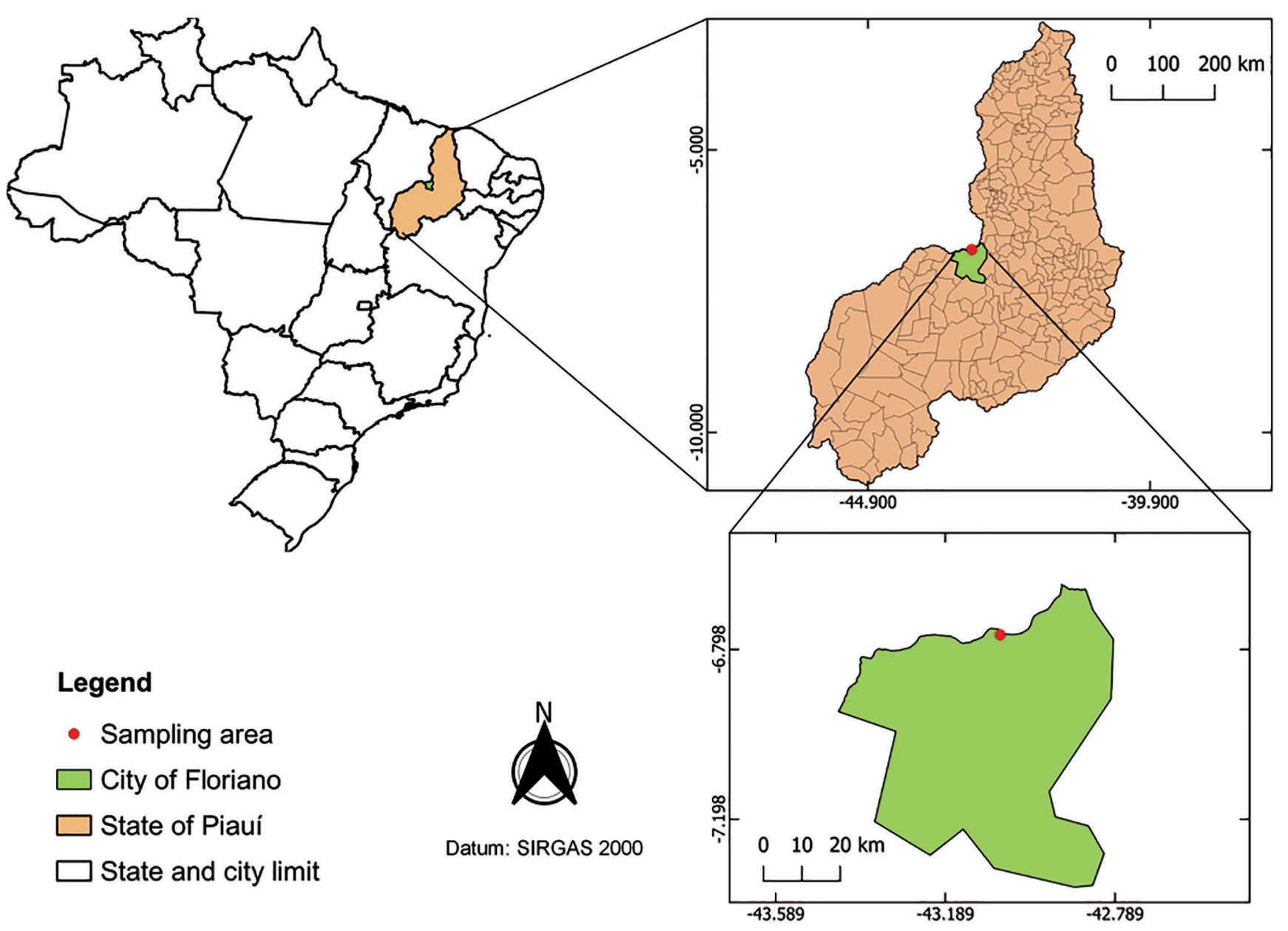

Figure 1. Map of the study area in Floriano county, state of Piauí, Brazil.

used and recommended for sampling ants (Delabie et al., 2021).

The biological material resulting from the collections was examined, separating the ants from the other arthropods, and the specimens were conditioned in alcohol $70 \%$. Subsequently, they were sent to the Myrmecology Laboratory of the Cocoa Research Center (CEPEC/ (EPLAC) at Ilhéus, Bahia, Brazil. The ants were mounted and identified at the highest specific level possible using identification keys (Kempf, 1951; Cuezzo, 2000; Schmidt \& Shattuck, 2014; Baccaro et al., 2015; Bolton, 2021) and comparison with the reference collection at the Myrmecology Laboratory of the Cocoa Research Center (CPDC, Delabie et al., 2020). Vouchers were deposited in the CPDC collection.

\section{Statistical analysis}

We used a paired t-test to assess whether the average number of ants recorded in the samples differed between the two seasons. To determine whether there was a difference in the composition of ant assemblies according to seasonality, an analysis of similarities (ANOSIM) was performed using Bray-Curtis dissimilarity distance, followed by similarity percentage analysis (SIMPER) to determine which species contributed the most to the dissimilarity between the seasons. We used non-metric multidimensional scaling (NMDS) to illustrate the relationship between the variables, using the Jaccard similarity index as the association measure. For this, we considered the presence/absence of each ant species per sampling points. Statistical analyses were performed using PAST 4.02 (Hammer et al., 2001) and R 3.6.1 (R Core Team, 2019), using the package "vegan" (Oksanen et al., 2019).

\section{RESULTS}

We collected a total of 31 ant species/morphospecies belonging to 14 genera and five subfamilies: Myrmicinae (64,5\% of the species), Formicinae (16\%), Dolichoderinae, Ectatomminae, and Ponerinae (6.5\% each). Of these 31 species, 28 were recorded during the rainy season and 17 during the dry season (Table 1 ). The most representative genera in the study were Pheidole (11 species), Camponotus (four spp.), and Solenopsis (three spp.). There were approximately four times more Pheidole species in activity during the rainy season than in the dry season. The ant species with the highest frequency of occurrence in the study were Camponotus crassus Mayr, 1862, Dinoponera quadriceps Kempf, 1971 (both recorded in 93.6\% of the sampling points), Pheidole (group Diligens) sp.01 (occurring in 70\% of points), Pheidole radoszkowskii Mayr, 1884 (63.3\%), Camponotus melanoticus Emery, 1894 (50\%), Pheidole diligens (Fr. Smith, 1858) (43.3\%), 
Table 1. List of ant species collected in an ecotonal area between the Caatinga and Cerrado biomes at Floriano, Piauí, Brazil. The values represent the number of occurrences of each species according to the methodology used. Species indicated with an asterisk ${ }^{*}$ ) represent new records for the state of Piauí.

\begin{tabular}{|c|c|c|c|c|c|c|c|}
\hline \multirow{2}{*}{ Subfamily } & \multirow{2}{*}{ Species } & \multicolumn{3}{|c|}{ Rainy season } & \multicolumn{3}{|c|}{ Dry season } \\
\hline & & Tree bait & Soil bait & Pitfall & Tree bait & Soil bait & Pitfall \\
\hline \multirow[t]{2}{*}{ Dolichoderinae } & Forelius brasiliensis (Forel, 1908) & & 1 & 5 & & & 2 \\
\hline & Forelius maranhaoensis Cuezzo, 2000* & & & 5 & 1 & & 4 \\
\hline \multirow[t]{2}{*}{ Ectatomminae } & Ectatomma muticum Mayr, 1870* & & & 5 & & & 2 \\
\hline & Gnamptogenys moelleri (Forel, 1912)* & & & & & & 1 \\
\hline \multirow[t]{5}{*}{ Formicinae } & Brachymyrmex heeri Forel, 1874 & & & 1 & & & \\
\hline & Camponotus atriceps (F. Smith, 1858)* & & & & & & 1 \\
\hline & Camponotus blandus (F. Smith, 1858) & 4 & 1 & 3 & 1 & & 1 \\
\hline & Camponotus crassus Mayr, 1862 & 9 & 4 & 16 & 3 & 8 & 28 \\
\hline & Camponotus melanoticus Emery, 1894 & & & 8 & & & 10 \\
\hline \multirow[t]{20}{*}{ Myrmicinae } & Acromyrmex rugosus (F. Smith, 1858) & & & & & 1 & 1 \\
\hline & Atta opaciceps Borgmeier, 1939 & 1 & & 1 & & & \\
\hline & Cephalotes pavonii (Latreille, 1809) & 1 & & & & & \\
\hline & Crematogaster erecta Mayr, $1866^{*}$ & & & 1 & & & \\
\hline & Crematogaster sp.01 & & & 1 & & & 1 \\
\hline & Cyphomyrmex transversus Emery, 1894 & & & 1 & & & \\
\hline & Pheidole (group Diligens) sp.01 & 2 & 7 & 19 & & & \\
\hline & Pheidole (group Diligens) sp.06 & 1 & & & & & \\
\hline & Pheidole (group Diligens) sp.07 & & & 2 & & & \\
\hline & Pheidole (group Diligens) sp.08 & & & 9 & & 1 & 5 \\
\hline & Pheidole (group Flavens) sp.02 & & & 1 & & & \\
\hline & Pheidole (group Tristis) sp.03 & & & 1 & & & \\
\hline & Pheidole (group Tristis) sp.04 & & & 1 & & & \\
\hline & Pheidole (group Tristis) sp.05 & & & 1 & & & \\
\hline & Pheidole (group Tristis) sp.06 & & & 4 & & & \\
\hline & Pheidole diligens (F. Smith, 1858) & & 3 & 10 & & 1 & 1 \\
\hline & Pheidole radoszkowskii Mayr, 1884* & & & 4 & & 2 & 25 \\
\hline & Solenopsis globularia (F. Smith, 1858)* & & & 1 & & & \\
\hline & Solenopsis sp.01 & & & 3 & & 1 & 2 \\
\hline & Solenopsis tridens Forel, 1911 & & 3 & 7 & & 3 & 6 \\
\hline \multirow[t]{2}{*}{ Ponerinae } & Dinoponera quadriceps Kempf, 1971 & & & 19 & & & 25 \\
\hline & Odontomachus bauri Emery, 1892 & & & 3 & & & 1 \\
\hline
\end{tabular}

Pheidole (group Diligens) sp.08, and Solenopsis tridens Forel, 1911 (36.6\% each) (Table 1).

A total of seven ant species recorded in this study are new species records for the state of Piauí: Brachymyrmex heeri Forel, 1874, Camponotus atriceps (Fr. Smith, 1858), Crematogaster erecta Mayr, 1866, Forelius maranhaoensis Cuezzo, 2000, Gnamptogenys moelleri (Forel, 1912), Pheidole diligens (Fr. Smith, 1858) and Solenopsis globularia (Fr. Smith, 1858).

We recorded three species that occurred only during the dry period: Acromyrmex rugosus (Fr. Smith, 1858), Ca. atriceps, and Gnamptogenys moelleri (Forel, 1912), while 14 species ( $45.2 \%$ of the total) occurred exclusively in the rainy season. Among these, we must emphasize the Atta opaciceps Borgmeier, 1939, B. heeri, Cephalotes pavonii (Latreille, 1809), and Cyphomyrmex transversus Emery, 1894, as unique species representing their respective genera in the study. The ant species $D$. quadriceps, Ectatomma muticum Mayr, 1870 and Odontomachus bauri Emery, 1892 are also as unique species representing their respective genera in the study, however they were recorded in both seasons (Table 1).

The pitfall trap was the most efficient sampling method, with 29 species collected in the study (93.5\%).
Cr. pavonii and Pheidole (group Diligens) sp.06 were only collected using bait on the trees (solely during the rainy period). None of the species occurred exclusively at baits on the ground. Camponotus crassus was the only species recorded in the three collection methods used, and in both seasons studied (Table 1).

We observed a greater diversity in the rainy season (Shannon-Wiener $=2.82$ ) than in the dry season (Shannon-Wiener $=2.18$ ). The average number of ants recorded in the rainy season $(4.9 \pm 1.66)$ was higher than that observed in the dry season $(3.67 \pm 1.65)(t=3.473$, $\mathrm{df}=29, P=0.002$ ) (Fig. 2).

The ant species composition of the seasonal assemblages was significantly different between seasons (ANOSIM $R=0.45 ; P<0.001$; Fig. 3 ), as the two periods showed approximately $66 \%$ of dissimilarity. The ant species with the highest contribution to the dissimilarity between seasons were Ph. gp. Diligens sp.01 (12.99\%) (collected exclusively in the rainy season), Ph. radoszkowskii (11.1\%), D. quadriceps (8.1\%), Ca. crassus (7.5\%) (all mostly collected in the dry season), Ca. melanoticus (7.4\%), Ph. diligens (7.3\%; mostly collected in the rainy season), and S. tridens (6.4\%). Eight ant species presented a contribution of $4 \%$ to $1 \%$ and 15 species from 1 to $0.2 \%$. 


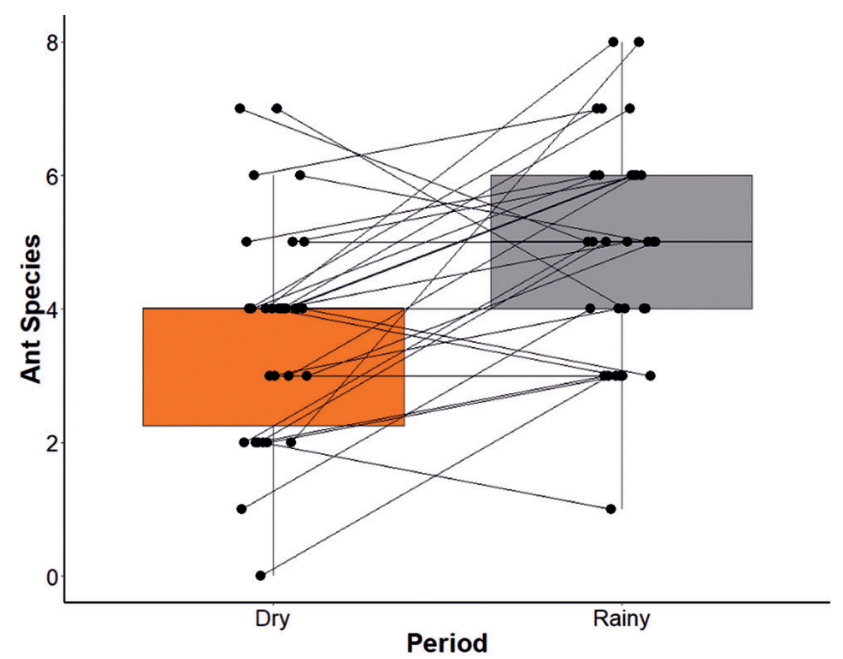

Figure 2. Number of ant species (average values) collected according to the seasons studied in a transition area between the Caatinga and Cerrado biomes in Floriano, Piauí, Brazil. The lines link the number of species caught in each collection point.

\section{DISCUSSION}

Our results demonstrate that both the number and occurrence of ant species were significantly different between the two seasons studied, corroborating our hypotheses. The low similarity between the ant assemblages in the different seasons likely indicates the effect of seasonality on ant activities in the ecotone. In dry tropical systems, previous studies have shown that environmental heterogeneity, resource availability and abiotic factors determine species richness and the composition of the ant assemblages (Leal et al., 2008; Fagundes et al., 2009; Gomes et al., 2010; Neves et al., 2013).

Studies on environmental heterogeneity and seasonal analysis (Coelho \& Ribeiro, 2006; Passos et al., 2016) demonstrated more significant ant activity in the rainy season, with the genera Camponotus and Pheidole being the most diverse. The subfamily Myrmicinae was dominant in our study, both in the number of species and in the number of genera. The predominance of Myrmicinae is a general pattern in ant studies in natural environments of the Neotropical Region (Hölldobler \& Wilson, 1990; Santos et al., 2017; Silva et al., 2017; Koch et al., 2019), and the state of Piauí is not an exception (Jory \& Feitosa, 2020). This subfamily represents about $50 \%$ of the diversity of known ant species (Bolton, 2021), and presents flexible feeding habits, behavioral dominance, and varied reproduction strategies (Fernández, 2003; Silvestre et al., 2003; Baccaro et al., 2015; Hamidi et al., 2017), as well as extreme adaptability to control large ecological niches in the Neotropical region (Fowler et al., 1991).

The most representative genera in this study reflect the results of Jory \& Feitosa (2020). These authors also observed Pheidole with the most significant number of species, followed by Solenopsis and Camponotus. In our study, Pheidole also showed the largest variation in the number of species between the two seasons studied, having greater activity during the rainy season. This genus is cosmopolitan, essentially pantropical and subtropical, and is generally well represented in the collection of soil ants, such as in forested areas (Leal, 2002; Bieber et al., 2006; Koch et al., 2019; Santos et al., 2017; Vasconcelos et al., 2017). Studies have shown that some Pheidole species are opportunist predators of a range of arthropods (Fernandes et al., 1994; Dejean et al., 2007; Lange et al., 2008), as well as some are associated with seed availability (Pirk et al., 2009; Lôbo et al., 2011). They can be scavengers and may explore as opportunists many other resources. Thus, a lower activity of these species is expected during the dry season, when the supply of these resources is smaller or limited, in relation to the

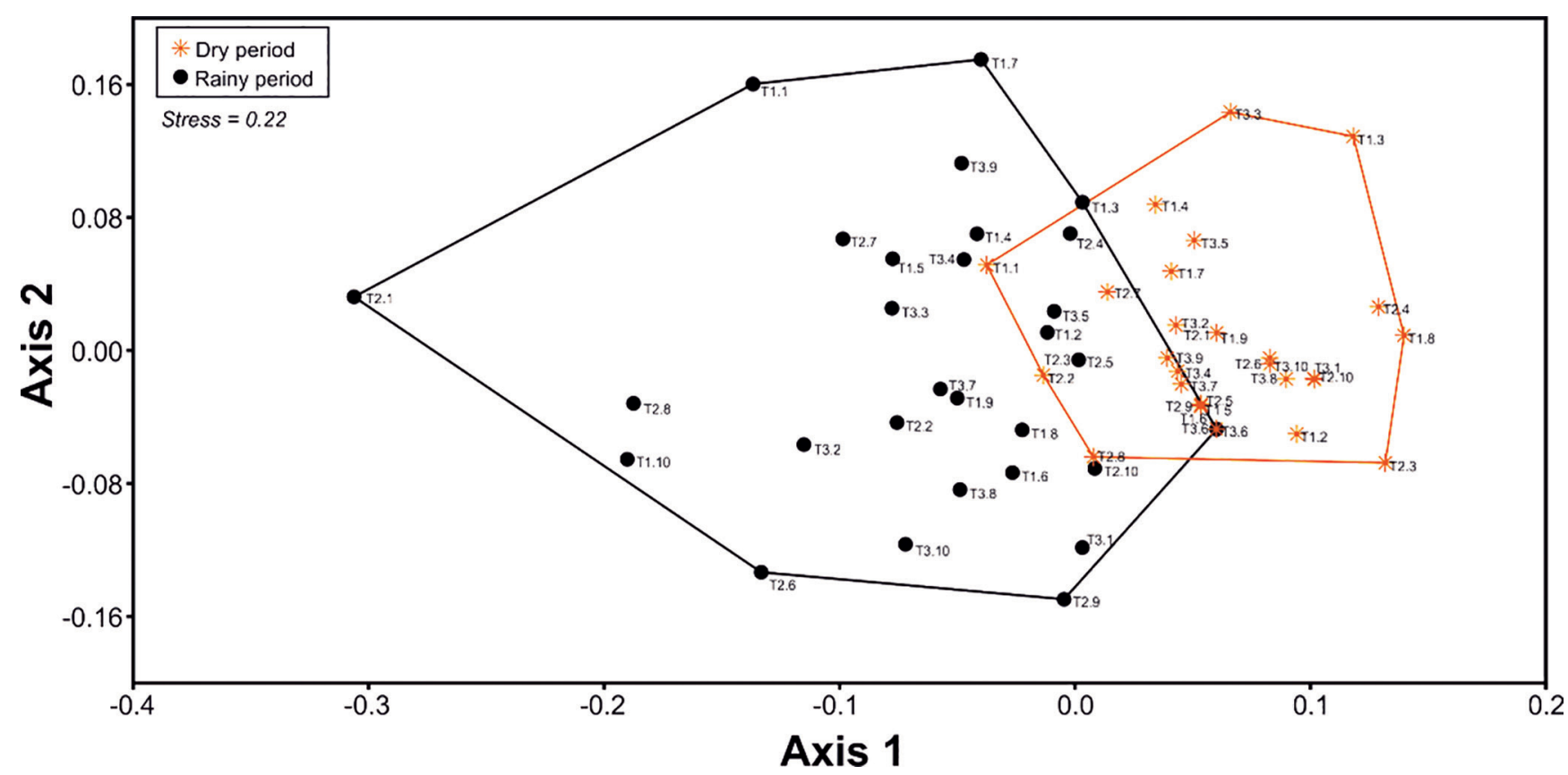

Figure 3. Non-metric multidimensional scaling - NMDS of ant composition according to seasonality in an ecotonal area between the Caatinga and Cerrado biomes at Floriano, Piauí, Brazil. 
rainy season. The low activity which was observed may be the consequence of a selective mortality on a range of species, but more certainly reflects the reduction in foraging activity (areas explored by workers, lower frequency of them) due to a probable decrease in populations of many species.

Camponotus is more present in biomes with characteristics of open habitats, such as Caatinga (Leal, 2003) and Cerrado (Ronque et al., 2016), while Solenopsis can be found in forested areas, countryside, savannas, as well as in disturbed areas, such as urban environments (Baccaro et al., 2015). Camponotus is a genus of generalist species, many of them interacting with sucking insects. It is possible that this last characteristic is somehow responsible with some aspect of the seasonality observed on this group.

Species of the genera Atta, Cephalotes, Cyphomyrmex and Brachymyrmex occurred only at a single sampling point, all occurring exclusively during the rainy season. Since species of these genera are commonly recorded in the Caatinga and Cerrado biomes (Leal, 2003; Vasconcelos et al., 2017), we do not record activities of these ants during the dry season certainly due to lower resource availability and likely adverse environmental conditions during this period.

Two species are highlighted in this study, C. crassus and $D$. quadriceps. The first species is dominant in the Cerrado, mainly in vegetation, although it forages on the ground (Del-Claro et al., 2016; Lange et al., 2019). This species is exclusively foraging during the day, both in the rainy and dry seasons (Lange et al., 2019). The second is endemic to the northeast region, occurring predominantly in the Caatinga biome (Lenhart et al., 2013). We believe that the maintaining of activity of these species during the dry period can be related to their great plasticity relative to climatic gradients and opportunism to food resources. Medeiros et al. (2012) demonstrated that in the Caatinga $D$. quadriceps shows peaks of foraging activities in drier periods of the years, and that this foraging activity is positively associated with prey availability (Medeiros et al., 2014). Ph. radoszkowskii is a notable exception in relation to all the other species of the genus Pheidole reported in this study, as it was mostly recorded in the dry season. This species is known to occur in open and dry habitats, including sites modified by human activity (Wilson, 2003; AntWiki, 2021). This species is extremely generalist, and may even present scavenger behavior on flies (Sales et al., 2016), but this ant owes above all to its great resistance to wide variations of temperature and humidity that it is active all year round, and especially during the dry season when competition with other species must decrease.

We have recorded seven new species occurrences for the state of Piauí. Among these, B. heeri was found in a single pitfall sample during the rainy season. This omnivorous and opportunistic species has a wide geographic distribution, being found in rainforest habitats as well as in synanthropic environments along roads, in undergrowth secondary vegetation or in pastures (AntWiki, 2021). In northeastern Brazil, this ant is report- ed for the states of Bahia and Maranhão (Antmaps, 2021). Ca. atriceps, although recorded in the present study in a soil sample during the dry season, is mostly an arboreal species that occurs in different types of environments and vegetation types, being generally considered a synanthropic species (AntWiki, 2021). Koch et al. (2016) recorded the species on Caryocar brasiliense Cambess. (Caryocaraceae), a common tree in Cerrado. Apparently, this ant has the ability to also transit on the ground (Koch et al., 2019). Another arboreal species, Cr. erecta also occurs in several habitat types, including seasonal dry and wet forests, apparently being more commonly found in open and even disturbed environments than mature forest (Longino, 2003). F. maranhaoensis was recorded in pitfall samples in both seasons, demonstrating that it is indeed a common species in the region. The genus Forelius presents species that generally nest in the ground and lives in dry habitats (Cuezzo, 2000). G. moelleri which was recorded in a single pitfall sample during the dry season, is known to be an epigaeic forager (AntWiki, 2021; Koch et al., 2019). However, this ant has already been reported on vegetation in the Pantanal (Dambros et al., 2018) or associated with epiphytic bromeliads on a large tree (Erythrina genus, Leguminosae) in a cocoa plantation (DaRocha et al., 2015). The other new reports are omnivorous soil species commonly found in several Brazilian biomes: Solenopsis globularia and Pheidole diligens. The first recorded in a single sample and the second most abundant during the rainy season. These new reports point out the needs and importance of further surveys of ants in the state of Piauí, as well as highlighting the importance of developping diversity studies in ecotones.

The observation of variations in ant foraging behavior according seasonality is certainly to be interpreted from the availability of resources, which must be linked to the loss of habitat heterogeneity during the dry season, one of the main factors related to the ant abundance (Fagundes et al., 2009). Caatinga marked seasonality causes drastic seasonal changes in the productivity and availability of resources for ants (Leal et al., 2008) and the same is true for the Cerrado, especially in more open vegetation types. Ant activity and diversity can vary according to the characteristics of the habitat, such as the structure of the vegetation, since more complex phytophysiognomies ensure greater opportunities of nesting sites and prey (Albuquerque \& Diehl, 2009; Gomes et al., 2010; Neves et al., 2013). Studies have shown that the richness and composition of ant assemblages can also be influenced by abiotic factors, such as litter depth, altitude, latitude, and climatic conditions, such as temperature and humidity (Vargas et al., 2007; Albuquerque \& Diehl, 2009, Gibb et al., 2015). At high thermal amplitude levels associated to a seasonal drought, stressful situations can occur because these factors limit the rates of growth, acquisition of resources, and reproduction of a number of organisms (Robinet \& Roques, 2010). Ants have a close relationship with climatic factors, such as temperature and humidity, and each species operates within a specific range of these ones (Andersen \& Majer, 2004). Although no climatic factor was evaluated in the 
present study, we believe that the differentiation in these factors and consequently in the supply of resources to the ants are the main responsible for the differences in the ant activity observed here.

\section{CONCLUSION}

In this study, we observed that the activity of ant fauna in a Cerrado-Caatinga ecotone is likely influenced by seasonality (dry and rainy seasons). This is only the second study that approaches the diversity of ants in the state of Piauí. Additionally, we present seven new ant species occurrence records for the state. More studies are needed to understand the processes and factors responsible for the activity patterns of ants. As our results refer to a single sampling event at each station, further studies should evaluate more accurately the processes involved in the ants' activities in Cerrado-Caatinga ecotones, preferably considering a longer period of time.

AUTHORS' CONTRIBUTIONS: VLM, MRAS: Conceptualization; VLM, MRAS, CSFM, JHCD, DBSB, LSO, JJMN: Methodology, Data curation, Formal analysis, Writing - original draft, Visualization, Investigation; VLM, EBAK, LSO, JJMN, DBSB, MRAS, CSFM, JHCD: Writing review \& editing. All authors actively participated in the discussion of the results, they reviewed and approved the final version of the paper.

CONFLICTS OF INTEREST: Authors declare there are no conflicts of interest.

FUNDING INFORMATION: This project did not use any external financial support.

ACKNOWLEDGMENTS: We are grateful to the Technical College of Floriano for the support in carrying out the study. We thank the Natural History Center for logistical support. Thanks to Lorena Beatriz Andrade for help with processing the ant specimens.

\section{REFERENCES}

Aguiar, L.M.S.; Camargo A.J.A. \& Moreira, J.R. 2008. Serviços ecológicos prestados pela fauna na agricultura do Cerrado. In: Parron L.M.; Aguiar, L.M.S.; Duboc, E.; Oliveira-Filho, E.C.; Camargo, A.J.A. \& Aquino, F.G. (Eds.). Cerrado: desafios e oportunidades para o maior desenvolvimento sustentável. Planaltina, Embrapa Cerrados. p. 193-228.

Aguiar, L.M.S.; Machado, R.B. \& Marinho-Filho, J. 2004. A diversidade biológica do Cerrado. In: Aguiar, L.M.S. \& Camargo, A.J.A. (Eds.). Cerrado: ecologia e caracterização. Brasília, Embrapa Informação Tecnológica. p. 19-39.

Albuquerque, E.Z. \& Diehl, E. 2009. Análise faunística das formigas epígeas (Hymenoptera: Formicidae) em campo nativo no Planalto das Araucárias, Rio Grande do Sul. Revista Brasileira de Entomologia, 53(3): 398-403. https://doi.org/10.1590/50085-56262009000300014.

Alonso, L.E. \& Agosti, D. 2000. Biodiversity studies, monitoring, and ants: an overview. In: Agosti, D.; Majer, J.D.; Alonso, L.E. \& Schultz, T.R. (Eds.).
Ants standard methods for measuring and monitoring biodiversity. Washington, Smithsonian Institution Press. p. 1-8.

Andersen, A.N. \& Majer, J.D. 2004. Ants show way Down Under: invertebrates as bioindicatorsinlandmanagement. FrontiersinEcologyandtheEnvironment, 2: 291-298. https://doi.org/10.1890/1540-9295(2004)002\%5b0292:AST WDU\%5d2.0.C0;2.

AntMaps. 2021. Available: http://antmaps.org. Access: 02/10/2021.

AntWiki. 2021. Available: https://www.antwiki.org. Access: 02/10/2021.

Baccaro, F.B.; Feitosa, R.M.; Fernandez, F.; Fernades, I.0.; Izzo, T.J.; Sousa, J.L.P. \& Solar R. 2015. Guia para gêneros de formigas do Brasil. Manaus, Editora INPA. p. $18-300$

Bieber, A.G.D.; Darrault, O.P.G.; Ramos, C.; Melo K.K. \& Leal, I.R. 2006. Formigas. In: Porto, K.L.; Tabarelli, M. \& Almeida-Cortez, J. (Eds.). Diversidade biológica e conservação da Floresta Atlântica ao norte do rio São Francisco. Recife, Editora Universitária da UFPE. p. 244-262.

Bolton, B. 2021. An online catalog of the ants of the world. Available: https:// antcat.org. Access: 16/09/2021.

Brandão, C.F.; Silva, R.R.; Feitosa, R.M. 2011. Cerrado ground-dwelling ants (Hymenoptera: Formicidae) as indicators of edge effects. Zoologia, 28(3): 379-387. https://doi.org/10.1590/S1984-46702011000300012.

Coelho, I.R. \& Ribeiro, S.P. 2006. Environment heterogeneity and seasonal effects in grounddwelling ant (Hymenoptera: Formicidae) assemblages in the Parque Estadual do Rio Doce, MG, Brazil. Neotropical Entomology, 35: 19-29. https://doi.org/10.1590/ S1519-566X2006000100004.

Cuezzo, F. 2000. Revisión del género Forelius (Hymenoptera: Formicidae: Dolichoderinae). Sociobiology, 35(2A): 197-275.

Dambros, J.; Vindica, V.F.; Delabie, J.H.C.; Marques, M.I. \& Battirola, L.D. 2018. Canopy ant assemblage (Hymenoptera: Formicidae) in two vegetation formations in the northern Brazilian Pantanal. Sociobiology, 65(3): 358-369. https://doi.org/10.13102/sociobiology.v65i3.1932.

DaRocha, W.D.; Ribeiro, S.P.; Neves, F.S.; Fernandes, G.W.; Leponce, M. \& Delabie, J.H.C. 2015. How does bromeliad distribution structure the arboreal ant assemblage (Hymenoptera: Formicidae) on a single tree in a Brazilian Atlantic forest agroecosystem? Myrmecological News, 21: 83-92.

Dejean, A.; Moreau, C.; Uzac, P.; Le Breton, J. \& Kenne, M. 2007. The predatory behavior of Pheidole megacephala. Comptes Rendus Biologies, 330(9): 701-709.

Delabie, J.H.C.; Koch, E.; Dodonov, P.; Caitano, B.; DaRocha, W.; Jahyny, B.; Leponce, M.; Majer, J. \& Mariano, C.S.F. 2021. Sampling and analysis methods for ant diversity assessment. In: Santos, J.C. \& Fernandes, G.W. (Eds.). Measuring Arthropod biodiversity - A handbook of sampling methods. Cham, Springer. p. 13-54.

Delabie, J.H.C.; Santos-Neto, E.A.; Oliveira, M.L.; Silva, P.S.; Santos, R.J.; Caitano, B.; Mariano, C.S.F.; Arnhold, A. \& Koch, E.B.A. 2020. A coleção de Formicidae do Centro de Pesquisas do Cacau (CPDC), Ilhéus, Bahia, Brasil. Boletim do Museu Paraense Emílio Goeldi, Ciencias Naturais, 15(1): 289-305. https://doi.org/10.46357/bcnaturais.v15i1.293.

Del-Claro, K.; Rico-Gray, V.; Torezan-Silingardi, H.M.; Alves-Silva, E.; Fagundes, R.; Lange D.; Dáttilo, W.; Vilela, A.A.; Aguirre, A. \& Rodriguez-Morales, D. 2016. Loss and gains in ant-plant interactions mediated by extrafloral nectar: fidelity, cheats and lies. Insectes Sociaux, 63(2): 207-21. https:// doi.org/10.1007/s00040-016-0466-2.

Divieso, R.; Rorato, A.; Feitosa, R.M.; Meyer, A.L. \& Pie, M.R. 2020. How to prioritize areas for new ant surveys? Integrating historical data on species occurrence records and habitat loss. Journal of Insect Conservation, 24(6): 901-911. https://doi.org/10.1007/s10841-020-00262-y.

Fagundes, R.; Santos.; N.B.E.; Silva, G.L.; Maia, A.C.R.; Santos, J.F.L. \& Ribeiro, S.P. 2009. Efeito das mudanças climáticas sazonais no forrageio de 
Formigas em uma área de mata estacional semidecidual Montana. In: Congresso de Ecologia do Brasil, $9^{\circ}$. Anais. São Lourenço, MG, Sociedade de Ecologia do Brasil.

Fernandes, W.D.; Oliveira, P.S.; Carvalho, S.L. \& Habib, M.E.M. 1994. Pheidole ants as potential biological control agents of the boll weevil, Anthonomus grandis (Col., Curculionidae), in Southeast Brazil. Journal of Applied Entomology, 118(4-5): 437-441.

Fernández, F. 2003. Subfamilia Myrmicynae. In: Fernández, F. (Ed.). Introduccion a las Hormigas de la region neotropical. Bogotá, Instituto de Investigacion de Recursos Biologicos. p. 307-327.

Fowler, H.G.; Forti, L.C.; Brandão, C.R.F.; Delabie, J.H.C. \& Vasconselos, H.L. 1991. Ecologia nutricional de formigas. In: Panizzi, A.R. \& Parra, J.R.P. (Eds.). Ecologia nutricional de insetos e suas implicações no manejo de pragas. São Paulo, Editora Manole. p. 131-223.

Freire, C.B.; Oliveira, G.V.; Martins, F.R.S.; Souza, L.E.C.; Ramos-Lacau, L.S. \& Corrêa, M.M. 2012. Riqueza de formigas em áreas preservadas e em regeneração de Caatinga arbustiva no sudoeste da Bahia, Brasil. Revista Brasileira de Biociências, 10: 131-134.

Gibb, H.; Sanders, N.J.; Dunn, R.R.; Watson, S.; Photakis, M.; Abril, S.; Andersen, A.N.; Angulo, E.; Armbrecht, I.; Arnan, X.; Baccaro, F.B.; Bishop, T.R.; Boulay, R.; Castracani, C.; Toro, I.D.; Delsinne, T.; Diaz, M.; Donoso, D.A.; Enríquez, M.L.; Fayle, T.M.; Feener-Jr., D.H.; Fitzpatrick, M.C.; Gómez, C.; Grasso, D.A.; Groc, S.; Heterick, B.; Hoffmann, B.D.; Lach, L.; Lattke, J.; Leponce, M.; Lessard, J.P.; Longino, J.; Lucky, A.; Mejer, J.; Menke, S.B.; Mezger, D.; Mori, A.; Munyai, T.C.; Paknia, 0.; PearceDuvet, J.; Pfeiffer, M.; Philpott, S.M.; Sousa, J.L.P.; Tista, M.; Vasconcelos, H.L.; Vonshak, M. \& Parr, C.L. 2015. Climate mediates the effects of disturbance on ant assemblage structure. Proceedings of the Royal Society B: Biological Sciences, 282(1808): 20150418. https://doi.org/10.1098/ rspb.2015.0418.

Gomes, J.P.; lannuzzi, L. \& Leal, I.R. 2010. Resposta da comunidade de formigas aos atributos dos fragmentos e da vegetação em uma paisagem da floresta Atlântica nordestina. Neotropical Entomology, 39(6): 898-905. https://doi.org/10.1590/S1519-566X2010000600008.

Gosz, J.R. 1993. Ecotone hierarchies. Ecological Applications, 3(3): 369-376. https://doi.org/10.2307/1941905.

Hamidi, R.; Biseau, J.C.; Bourguignon, T.; Segundo, G.B.M.; Fontenelle, M.T.M.B. \& Quinety, Y. 2017. Dispersal strategies in the highly polygynous ant Crematogaster (Orthocrema) pygmaea Forel (Formicidae: Myrmicinae). PloS One, 12: 01-22. https://doi.org/10.1371/journal. pone.0178813.

Hammer, 0;; Harper, D.A.T.; Ryan, P.D. 2001. PAST: Paleontological statistics software package for education and data analysis. Palaeontologia Electronica, 4: 1-9.

Holland, M.M. 1988. SCOPE/MAB technical consultations on landscape boundaries: report of a SCOPE/MAB workshop on ecotones. Biology International, 17: 47-106.

Hölldobler, B.; Wilson, E.0. 1990. The ants. Harvard, Harvard University Press. $746 p$.

Jory, T.T. \& Feitosa, R.M. 2020. First survey of the ants (Hymenoptera, Formicidae) of Piauí: filling a major knowledge gap about ant diversity in Brasil. Papéis Avulsos de Zoologia, 60(14): 02-08. https://doi. org/10.11606/1807-0205/2020.60.14.

Kark, S. \& Rensburg, B.J. 2006. Ecotones: marginal or central areas of transition? Israel Journal of Ecology and Evolution, 52: 29-53. https://doi. org/10.1560/JJEE.52.1.29.

Kempf, W.W. 1951. A taxonomic study on the ant tribe Cephalotini (Hymenoptera: Formicidae). Revista de Entomologia, 22: 1-244.

Klink, C.A. \& Machado, R.B. 2005. A conservação do Cerrado brasileiro. Megadiversidade, 1: 148-155.
Koch, E.B.A.; Camarota, F. \& Vasconcelos, H.L. 2016. Plant ontogeny as a conditionality factor in the protective effect of ants on a neotropical tree. Biotropica, 48(2): 198-205. https://doi.org/10.1111/btp. 12264.

Koch, E.B.A.; Santos, J.R.M.; Nascimento, I.C. \& Delabie, J.H.C. 2019. Comparative evaluation of taxonomic and functional diversities of leaflitter ants of the Brazilian Atlantic Forest. Turkish Journal of Zoology, 43(5): 437-456. https://doi.org/10.3906/z00-1811-7.

Lange, D.; Calixto, E.S.; Rosa, B.B.; Sales, T.A. \& Del-Claro, K. 2019. Natural history and ecology of foraging of the Camponotus crassus Mayr, 1862 (Hymenoptera: Formicidae). Journal of Natural History, 53(27-28): 1737-1749. https://doi.org/10.1080/00222933.2019.1660430.

Lange, D.; Fernandes, W.D.; Raizer, J \& Faccenda, 0. 2008. Predacious activity of ants (Hymenoptera: Formicidae) in conventional and in no-till agriculture systems. Brazilian Archives of Biology and Technology, 51(6): 1199-1207.

Leal, I.R. 2002. Diversidade de formigas no estado de Pernambuco. In: Tabarelli, M. \& Silva, J.M.C. (Eds.). Atlas da biodiversidade de Pernambuco. Recife, Editora da Universidade Federal de Pernambuco. p. 483-492.

Leal, I.R. 2003. Diversidade de formigas em diferentes unidades da paisagem da Caatinga. In: Leal, I.R.; Tabarelli, M. \& Silva, J.M.C. (Eds.). Ecologia e conservação da Caatinga. Recife, Editora da Universidade Federal de Pernambuco. p. 435-461.

Leal, I.R.; Tabarelli, M. \& Da silva, J.M.C. 2008. Ecologia e conservação da caatinga. 3.ed. Recife, Universidade Federal de Pernambuco. 822p.

Lenhart, P.A.; Dash, S.T. \& Mackay, W.P. 2013. A revision of the giant Amazonian ants of the genus Dinoponera (Hymenoptera, Formicidae). Journal of Hymenoptera Research, 31: 119-164. https://doi.org/10.3897/ JHR.31.4335.

Lôbo, D.; Tabarelli, M. \& Leal, I.R. 2011. Relocation of Croton sonderianus (Euphorbiaceae) seeds by Pheidole fallax Mayr (Formicidae): a case of post-dispersal seed protection by ants? Neotropical Entomology, 40(4): 440-444. https://doi.org/10.1590/S1519-566X2011000400005.

Longino, J.T. 2003. The Crematogaster (Hymenoptera, Formicidae, Myrmicinae) da Costa Rica. Zootaxa, 151: 1-150.

Majer, J.D. 1996. Ant recolonization of rehabilitated bauxite mines at Trombetas, Pará, Brazil. Journal of Tropical Ecology, 12(2): 257-273.

Marinho, C.G.S. Zanetti, R.; Delabie, J.H.C.; Shlindwein, M.N. \& Ramos, L.S. 2002. Diversidade de formigas (Hymenoptera: Formicidae) da Serapilheira em Eucaliptais (Myrtaceae) e Área de Cerrado de Minas Gerais. Neotropical Entomology, 31(2): 187-195. https://doi.org/10.1590/ S1519-566X2002000200004.

Medeiros, J.; Araújo, A.; Araújo, H.P.F.; Queiroz, J.P.C. \& Vasconcellos, A. 2012. Seasonal activity of Dinoponera quadriceps Santschi (Formicidae, Ponerinae) in the semi-arid (aatinga of northeastern Brazil. Revista Brasileira de Entomologia, 56: 81-85. https://doi.org/10.1590/ S0085-56262012000100013.

Medeiros, J.; Azevedo, D.L.O.; Santana, M.A.D.; Lopes, T.R.P. \& Araújo, A. 2014. Foraging Activity Rhythms of Dinoponera quadriceps (Hymenoptera: Formicidae) in Its Natural Environment. Journal of Insect Science, 14: 02-09. https://doi.org/10.1093/jisesa/ieu082.

Ministério do Meio Ambiente (MMA). 2017. Áreas prioritárias Avaliação - Caatinga. Available: http://areasprioritarias.mma.gov. br/2-atualizacao-das-areas-prioritarias.

Neves, F.S.; Queiroz-Dantas, K.S.; Darocha, W.D.; Delabie, J.H.C. 2013. Ants of three adjacent habitats of a transition region between the cerrado and caatinga biomes: The effects of heterogeneity and variation in Canopy cover. Neotropical Entomology, 42(3): 258-268. https://doi.org/10.1007/ s13744-013-0123-7.

Nunes, F.A.; Martins, S.G.B.; Vasconcelos, Y.B.; Azevedo, R. \& Quinet, Y. 2011. Groud-foraging ants (Hymenoptera: Formicidae) and rainfall effect on 
pitfall trapping in a deciduous thorn woodland (Caatinga), Northeastern Brazil. Revista de Biologia Tropical, 59(4): 1637-1650.

Oksanen, J.; Blanchet, F.G.; Friendly, M.; Kindt, R.; Legendre, P.; McGlinn, D. \& Stevens, M.H.H. 2019. Vegan: Community Ecology Package, 2: 5-6. Available: https://cran.r-project.org/web/packages/vegan/vegan.pdf.

Passos, D.C.; Mesquita, P.C.M.D. \& Borges-Nojosa, D.M. 2016. Diversity and seasonal dynamic of a lizard assemblage in a Neotropical semiarid habitat. Studies on Neotropical Fauna and Environment, 51: 19-28. https://doi.org/10.1080/01650521.2016.1149383.

Pirk, G.I.; di Pasquo, F. \& de Casenave, J.L. 2009. Diet of two sympatric Pheidole spp. ants in the central Monte desert: implications for seedgranivore interactions. Insectes Sociaux, 56(3): 277-283. https://doi. org/10.1007/s00040-009-0021-5.

Robinet, C. \& Roques, A. 2010. Direct impacts of recent climate warming on insect populations. Integrative Zoology, 5(2): 132-142. https://doi. org/10.1111/j.1749-4877.2010.00196.x.

Ronque, M.U.V.; Azevedo, S.M.; Mori, G.M.; Souza, A.P. \& Oliveira, P.S. 2016. Three ways to distinguish species: using behavioural, ecological, and molecular data to tell apart two closely related ants, Camponotus renggeri and Camponotus rufipes (Hymenoptera: Formicidae). Zoological Journal of the Linnean Society, 176(1): 170-181. https://doi.org/10.1111/ zoj. 12303 .

Sales, T.A.; Daemon, E. \& Lopes, J.F. 2016. Necrophagous or predators? The role of Pheidole radoszkowskii Mayr (Hymenoptera: Formicidae) on Rattus norvegicus (Berkenhout) carcasses (Rodentia: Muridae). Journal of Natural History, 50(15-16): 971-974. https://doi.org/10.1080/00222 933.2015.1091100.

Santos, R.J.; Koch, E.B.A.; Leite, C.M.P.; Porto, T.J. \& Delabie, J.H.C. 2017. An assessment of leaf-litter and epigaeic ants (Hymenoptera: Formicidae) living in different landscapes of the Atlantic Forest Biome in the State of Bahia, Brazil. Journal of Insect Biodiversity, 5: 1-19. https://doi. org/10.12976/jib/2017.5.19.

Schmidt, C.A. \& Shattuck, S.0. 2014. The higher classification of the ant subfamily Ponerinae (Hymenoptera: Formicidae), with a review of Ponerinae ecology and behavior. Zootaxa, 3817(1): 1-242.

Silva, E.M. \& Delabie, J.H.C. 2014. Formicidae (Hymenoptera) do Semiárido. In: Bravo, F. \& Calor, A. (Eds.). Artrópodes do Semiárido, Biodiversidade e Conservação. Feira de Santana, Printmídia. p. 203-213.
Silva, L.F.; Souza, R.M.; Solar, R.R.C.; Neves, F.S. 2017. Ant diversity in Brazilian tropical dry forests across multiple vegetation domains. Environmental Research Letters, 12: 1-11.

Silvestre, R.; Brandão, C.R.F. \& Silva, R.R. 2003. Grupos funcionales de hormigas: El caso de los 693 gremios del Cerrado, Brasil. In: Fernández F. (Ed.). Introducción a las hormigas de la región neotropical. Bogotá, Instituto Humboldt Bogotá. p. 113-143.

Smith, T.B.; Wayne, R.K.; German, D.J. \& Bruford, M.W. 1997. A role for ecotones in generating rainforest biodiversity. Science, 276(5320): 1855-1857. https://doi.org/10.1126/science.276.5320.1855.

The R Project for Statistical Computing (R Core Team). 2019. R: A language and environment for statistical computing. Vienna, R Foundation for Statistical Computing. Available: http://www.r-project.org.

Tibcherani, M.; Nacagava, V.A.F.; Aranda, R. \& Mello, R.L. 2018. Review of ants (Hymenoptera: Formicidae) as bioindicators in the Brazilian Savanna. Sociobiology, 65(2): 112-129. https://doi.org/10.13102/sociobiology. v65i2.204.

Ulysséa, M.A. \& Brandão, C.R.F. 2013. Ant species (Hymenoptera, Formicidae) from the seasonally dry tropical forest of northeastern Brazil: a compilation from field surveys in Bahia and literature records. Revista Brasileira de Entomologia, 57: 01-09. https://doi.org/10.1590/ S0085-56262013005000002.

Vargas, A.B.; Mayhe-Nunes, A.J.; Queiroz, J.M.; Orsolon, G.S. \& Folly, R.E. 2007. Efeito de fatores ambientais sobre a mirmecofauna em comunidade de restinga no Rio de Janeiro, RJ. Neotropical Entomology, 32: 28-37. https:// doi.org/10.1590/S1519-566X2007000100004.

Vasconcelos, H.L.; Carvalho, K.S.; Delabie, J.H.C. 2001. Landscape modifications and ant communities. In: Bierregaard, R.0.; Gascon, C.; Lovejoy, T.E. \& Mesquita, R. (Eds.). Lessons from Amazonia: the ecology and conservation of a fragmented forest. New Haven, Yale University Press. p. 199-207.

Vasconcelos, H.L.; Maravalhas, J.B.; Feitosa, R.M.; Pacheco, R.; Neves, K.C.; Andersen, A.N. 2017. Neotropical savanna ants show a reversed latitudinal gradient of species richness, with climatic drivers reflecting the forest origin of the fauna. Journal of Biogeography, 45: 248-258. https://doi.org/10.1111/jbi.13113.

Wilson, E.0. 2003. Pheidole in the new world: a dominant, hyperdiverse ant genus. Cambridge, Harvard University Press. 794p. 